\title{
Phenotypic relations between egg weight and other egg quality traits of South
} Eastern Nigeria local chicken

A. I. Adeolu and V.U. Oleforuh-Okoleh.

${ }^{1}$ Department of Agricultural Education, Ebonyi State College of Education, P.M.B. 02 Ikwo, Nigeria Sankarafarms@yahoo.com

${ }^{2}$ Department of Animal Science, Ebonyi State University, P.M.B. 53 Abakaliki, Nigeria

vivewa@yahoo.co.uk

\begin{abstract}
The experiment was carried out with a total of one hundred and fifty eggs, which were collected from a local chicken variety of southeastem Nigeria hens reared in a cage system. The objective of this study was to determine the phenotypic relationship between egg weight and the other egg quality traits. The mean values related to the external egg quality traits - egg weight $(E W)$, egg length (EL), egg breadth (EB), egg shape index (ESI), shell weight (SW) and shell thickness (ST) were $38.99 \mathrm{~g}, 49.98 \mathrm{~mm}$, $36.66 \mathrm{~mm}, 0.73,4.05 \mathrm{~g}$ and $0.34 \mathrm{~mm}$ respectively. The internal egg quality traits albumen height $(A H)$, albumen weight $(A W)$, yolk height $(Y H)$, yolk weight $(Y W)$ and Haugh unit (HU) have the following mean values, $7.53 \mathrm{~mm}, 19.86 \mathrm{~g}, 16.80 \mathrm{~mm}, 12.62$ $g$ and 65.21 respectively. There were significant $(P<0.01)$ positive phenotypic correlations between $E W$ and $E L, E W$ and $E B, E W$ and $S W$, and between $E W$ and all the internal quality traits except $H U$ - which had a non significant $(P>0.01)$ negative correlation. Significant negative correlation was found between EW and ESI. It was concluded that it was feasible to assess some egg quality traits through the egg weight. This is important in view of integrating the local chicken into egg laying breeding programs in Nigeria.
\end{abstract}

Key words: Local chicken, egg weight, egg quality characteristics, phenotypic correlation

\section{Introduction}

The economic potentials of poultry are substantially derived from the productivity of the breeding hen. Compared to other important meat producing animals, poultry can be improved at an extremely rapid rate. The egg of chicken is a biological structure intended by nature for reproduction and it also provides a complete diet for the developing embryo (Shi et al., 2009). In Nigeria, practically many household keeps poultry especially in rural communities and majority of such birds are the chickens. The type of chicken kept and their management are highly influenced by various biological, cultural, social and economic factors prevailing in the communities. To the poor majority in rural areas, local chickens serve as an immediate source of meat and income when money is needed for urgent family needs (Ekue et al., 2002). Furthermore, they constitute a significant contribution to human livelihood and contribute significantly to food security. Most importantly, they are known for their adaptive hardiness and superiority in terms of their resistance to endemic diseases and other harsh environmental conditions (Malago and Baitilwake, 2009). 
In Nigeria, egg is more affordable by the populace than other sources of animal protein such as beef, pork, fish, etc. The external and internal quality traits of eggs are significant in poultry breeding because of their influence on the yield features of the future generations, breeding performance, quality and growth of the chicks (Altinel et al., 1996), and consumers' preferences. Among these traits, egg weight (EW) is an important trait that influences egg quality as well as grading (Farooq et al., 2001). It is of much relevance to the poultry breeder because it is a trait that can be determined without breaking the egg. According to USDA (2000) egg weights in the USA are classified as: peewee $(<42 \mathrm{~g})$, small $(42-49$ g), medium (49-56 g) large (56-65 g), extralarge (65-70 g) and jumbo (70 $\mathrm{g}$ and above). Although egg grading practice is not applicable in most poultry farms in Nigeria, Ewa et al. (2005) reported that the normal egg size of the Nigerian local chicken is classified as peewee using the standard grading system.

The external and internal quality traits of eggs of hens as well as the relationship between them have been reported by many authors (Poggenpoel, 1986; Uluocak, 1990; Sekeroglua and Altuntas, 2009). However, most of these studies were on exotic chickens. There are little studies reported about the relationship between egg weight and other egg quality traits in the Nigerian local chicken. For instance, Nigeria has rich chicken genetic resources and their performances vary considerably both in egg quality and other production traits. Fayeye (2005) and Peters et al. (2007) worked on egg traits, fertility and hatchability of the Fulani ecotype, and influence of major genes on the egg quality in the Nigerian local chicken respectively. The objectives of current study were to estimate the egg weight, egg shape index, shell weight, shell thickness, albumen weight, yolk weight, albumen height, yolk height, and Haugh unit of the southeastern Nigeria local chicken and to investigate the relationships between egg weight and each of these egg quality traits.

\section{Materials and Methods}

A total of 150 eggs were collected from the local chicken breeding farm of Department of Animal Science, Ebonyi State University, Abakaliki, Nigeria. Abakaliki is located between Latitude $06^{\circ} 4^{\prime} \mathrm{N}$ and Longitude $08^{\circ} 65^{\prime} \mathrm{E}$ in the derived savanna ecological zone of Nigeria. The day length of Abakaliki ranges between 12-14 hours all year round, it has an annual rainfall range of between 1500-2250 mm with mean daily temperature ranges of $27^{\circ} \mathrm{C}$ and relative humidity of $85 \%$ (Nwakpu, 2005). Evaluated eggs were collected from the $F_{1}$ generation of southeastern Nigerian local chicken obtained from selected light local chicken ecotype (Adeolu et al., 2008) raised to serve a breeding purpose. The layers were 280 days of age and were housed individually in a three-tier layer cage of dimension $(17 \mathrm{~cm} \times 32 \mathrm{~cm} \times 32 \mathrm{~cm})$. The hens were given commercial layer diet ad libitum containing $17 \% \mathrm{CP}$ and $2800 \mathrm{ME}$ $\mathrm{Kcal} / \mathrm{kg}$. A lighting schedule of 14 hours lighting/day was applied.

\section{Egg measurements}

All eggs for investigation were collected within three consecutive days in a week over four weeks. Egg measurements were assessed for both external and internal egg quality traits. The weights value of egges (EW), shell (SW), albumen (AW) and yolk (YW) of each egg were weighed to the nearest 0.10 gram using a digital Mettler P1020 weighing scale while egg length (EL) and egg breadth (EB) were measured to the nearest $0.10 \mathrm{~mm}$ using a pair of vernier caliper. The values of the egg length (EL) and egg breadth (EB) were used 
to determine the egg shape index (ESI). An electrenic micrometer and height gauge were used to measure the thickness of the shell (ST) in mm and the albumen (AH) and yolk height $(\mathrm{YIH})$ respectively. Haugh unit (HU) was automatically calculated using the system of the input of egg weight and albumen height as cited by Kul and Seker (2004).

\section{Data analysis}

Data were analyzed using SPSS 11.0 Packet Frogram and Descriptive statistics like the mean (X), standard error of mean (SEM) and coefficient of variation (CV). Differences in the correlation coefficients of properties were determined and significance tests were applied, using Correlate of SPSS 11.0 .

Table 1: Descriptive statistics of egg quality trait

\begin{tabular}{lccc}
\hline Traits* & Mean & SEM & CV \\
\hline External traits & & & \\
EWT(g) & 38.99 & 0.37 & 0.08 \\
EL(mm) & 49.98 & 0.23 & 0.04 \\
EB(nm) & 36.66 & 0.12 & 0.03 \\
ESI & 0.73 & 0.01 & 0.04 \\
ST(mm) & 0.34 & 0.01 & 0.23 \\
SW $(g)$ & 405 & 0.05 & 0.11 \\
Internal traits & & & \\
AW(g) & 19.86 & 0.26 & 0.13 \\
AH(mm) & 753 & 0.15 & 0.16 \\
YW(g) & 12.62 & 0.14 & 0.1 \\
YH(mm) & 16.8 & 0.13 & 0.07 \\
HU(\%) & 65.21 & 1.16 & 0.22 \\
& & &
\end{tabular}

*See Materials and Methods for key to codes

\section{Results and Discussion}

The descriptive statistics related to the various egg quality traits studied are shown in Table I. The CV for all traits measured were generally less than $0.25 \%$. The results of the current study showed that the southeastern Nigeria local chicken had lower egg weight than those reported for other breeds such as White Leghorn (45.5 g), Fayoumi (42.24 g) and RIR (43.4 g) (Mekky et ai., 2008). The value was also lower than those of around $40 \mathrm{~g}$ given by Fayeye et al. (2005) for the Fulani ecotype and $47.23 \mathrm{~g}$ reported by Peters et al. (2007) for the normal feather Nigeria local chicken. It is also very close to the findings of Soltan (1991) for the Fayoumi (37.3 g) and Baladi (39.2 g) chickens. The mean EL, EB, ESI, ST, SW of local chicken in the present study were consistent to values reported by Ewa et al. (2005) and Yakubu et al. (2008), respectively. The mean AW (19.86) and $\mathrm{AH}(7.53 \mathrm{~mm})$ observed were close to $20.33 \quad 3.06 \mathrm{~g}$ and respectively reported by (Zhang et al., 2005) but varied greatly from the results of the normal feather local chicken reported by Peters et $a l$. (2007). The southeastern Nigerian local chicken outperformed their counterpart normal feathered and Fulani-ecotype in YH but the trend was in reversed in YW. The differences found between the present result and those of other researchers may be partially attributable to differences in lines (genetic structure),

Table 2: The phenotype correlations between egg weight and other egg quality traits of loc al chicken egg

\begin{tabular}{cc}
\hline $\begin{array}{c}\text { Egg quality } \\
\text { traits }^{1}\end{array}$ & $\begin{array}{c}\text { phenotypic } \\
\text { correlation }\end{array}$ \\
\hline EL & $0.18^{* *}$ \\
EB & $0.73^{* *}$ \\
ESI & $-0.35^{* *}$ \\
ST & 0.12 \\
SW & $0.41^{* *}$ \\
AW & $0.75^{* *}$ \\
YW & $0.53^{* *}$ \\
AH & $0.23^{* *}$ \\
YH & $0.44^{* *}$ \\
HU & -0.05 \\
\hline
\end{tabular}

$* * \mathrm{P}<0.01$

${ }^{1}$ See materials and methods for key to codes 
nutrition, age and environment. The Haugh unit, an important criterion for determining the internal quality traits of the egg (Olawumi and Ogunlade, 2009) had a good percentage (65.21). This is similar to the value obtained by Peters et al. (2007) for the naked neck local chicken (65.68). The local chicken egg assessed in the present study, thus, belong into the " $A$ " quality grading category (USDA, 2000).

Correlation coefficients between egg weight and other egg quality traits are shown in Table 2. The reported estimates of the phenotypic correlation between EW and other egg quality traits studied were consistent with the reports of various authors. Ewa et al. (2005) reported a significant positive association between $\mathrm{EW}$ and $\mathrm{EL}, \mathrm{EW}$ and $\mathrm{EB}$. In the present study, correlation between EW and egg shape index confirmed the findings of Abanikannda et al. (2007) and Yakubu et al. (2008). Gunlu et al. (2003) attributed this to the fact that EL is the denominator factor in estimating ESI. The association between EW and ST in the present study though positive was not significant $(\mathrm{P}>0.05)$. There have been reports of positive correlation between egg weight and shell thickness (Ewa et al., 2005; Shi et al., 2009). Sekeroglua and Altuntas (2009) in their study of effects of egg weight on egg quality characteristics noted that smaller eggs had stronger shells than larger ones, as hens have a finite capacity to deposit calcium in the shell and, as a result, the same amount of calcium is spread over a larger area.

Egg weight had a significant positive association with AW and YW $(\mathrm{P}<0.01)$. Sekeroglua and Altuntas (2009) found significant differences in albumen and yolk percentage with different egg sizes. The proportion of yolk tended to be greater than the proportion of albumen in smaller eggs than larger ones. The finding of the present study with regards to the relationship between EW and HU was consistent with those of Iposu et al. (2004). Mohanty et al. (1986) and Shi et al. (2009) reported a positive relationship between EW and $\mathrm{AH}$. Their report is consistent with that of the present study.

\section{Conclusion}

In conclusion, this study has shown that there is an association (either positively or negatively) between egg weight and other egg quality traits. Most of these were positive indicating that these egg quality traits can significantly be improved through breeding for the improvement of the egg weight. Furthermore, in this era of genetic conservation, it is imperative to integrate the local chicken into the layer - breeding programs. To achieve this, more studies are needed to explore other factors like growth performance, production (in terms of carcass weight and egg number), disease resistance and adaptability to harsh environment of the Nigerian local chicken. Findings from such studies and the ones presented here could be a significant prelude to the improvement of this chicken either through selection, pure breeding and or crossbreeding programme.

\section{References}

Abanikannda O. T. F., Olulogun, O., Leigh, A. O. and Ajayi, L.A. 2007. Statistical modeling of egg dimensions in commercial layers. Inter. $J$ of Poult. Sc. 6(1):59-63.

Adeolu, A. I., Oleforuh-Okoleh, V. U., and Otuma, M. O. 2008. Estimates of genetic parameters for egg production traits of the local chicken in southeastern Nigeria. Proc. of the $13^{\text {th }}$ Ann. conf. of Anim. Sci. Assoc. of Nigeria (ASAN) 
Sept. 15-19-2008. ABU Zaria.

Altinel, A., Guneb, H., Kirmizibayrak, T., Corekei and Bilal, T. 1996. The studies on egg quality characteristics of Japaneze quails. J. Fac. Vet. Univ.Istanbul 22:203-212.

Ekue, F. N., Poné, K. D., Mafeni, M. J., Nfi, A. N. and Njoya, J. 2002. Survey of the traditional poultry production system in the Bamenda area, Cameroon. In: Characteristics and Parameters of Family. PP 10-45

Ewa V.U., Otuma, M.O. and Omeje, S. I. 2005. Interrelationships of external egg quality traits of four inbred line chicken strains. Tropical J. Anim. Sci. 8(1):2336.

Farooq, K. A. M., Mian .A., Ali, M., Durrani, F. R., Asquar, A., and Muquarrab, A.K.2001. Eggs traits of Fayomi bird under subtropical conditions. Sarad, J. Agric 17:141-145.

Fayeye, T. R. Adeshiyan, A. B. and Olugbani, A. A. 2005. Egg traits, hatchability and early growth performance of the Fulani ecotype chicken, Liv. Res. For Rural Dev. 17(8)

Gunlu, A., Kiriki, K., Cetin, O. and Carip, M. 2003. Some external and internal quality characteristics of partridge (A. gracca) eggs. Food Agric Environ. 1: 197-199.

Iposu, S. O.; Onwuka, C. F. I. and Eruvbetine, D. 1994. The relationship between selectedquality traits and egg size. Nig. J. Anim. Prod. 21:156160.

Kul, S. and Seker, I. 2004. Phenotypic correlation between some externals and internal egg quality traits in the Japanese quail (Cotunaix coturnix japonica). International Journal of Poultry science. 3(6):400-405.

Malago, J.J. and Baitilwake, M.A. 2009. Egg traits, fertility, hatchability and chick survivability of Rhode Island Red, local and crossbred chickens. Tanzania Vet. Journal Vol. 26, No. 1: 24-36.

Mekky, S.S., Galal, A., Zaky, H.I. and Zen EI Dein, A. 2008. Diallel crossing analysisfor body weight and egg production traits of two native Egyptian and two exotic chicken bre eds. Int. J. of Poult. Sci. 7(1):64-71.

Mohanty, S. C., Kanungo, H. and Mishra, M. 1986. Effect of age at laying on the quality of egg of $\quad \mathrm{w} \mathrm{h} \mathrm{it} \mathrm{e}$ leghorn hens. Indian J. Anim. Prod. Manage. 2:184-186.

Nwakpu, C. 2005. Practical guide to lowland rice production in Nigeria. $1^{\text {st }}$ Ed. SNAAP Press Ltd. Enugu.

Olawumi, S.O. and Ogunlade, J.T. (2009). The effects of genotype and age of layer breeders on egg quality Traits. Nig. J. Anim. Production. 36(2): 228236

Peters, S. O., Ikeobi, C.O.N., Ozoje, M.O., Famakinwa, O.A., Oshodi, Y.S. and Adebambo, O.A. 2007. Egg quality of the Nigerian Local Chicken as Influence by Some Major Genes. Nig. J. of Anim. Prod. 34(1):25-31.

Poggenpoel, D. G. 1986. Correlated response in shell and albumen quality withselectionfor increased e g g production. Poult. Sci. 65:1633-1641.

Sekeroglua, A. and Altuntas, E. 2009. Effects of egg weight on egg quality characteristics. J. Sci. Food A gric. 89:379-383.

Shi, R. S., Wang, K. H., Dou, T. C. and Yang, H. M. 2009. Egg weight affects some quality traits of chicken eggs. Journal of Food, Agriculture \& Environment Vol, 7 (2): 432 -434.

Soltan, M.E. 1991. Direct response in egg production from selection on early part records and correlated responses in some economic traits as a result of this 
selection in Sinai (Bedouion) fowl. Minufiua J. of Agric. Res. 16:373-417.

SPSS for Windows. (2002). Release 11.0 Standard Version. Copyright SPSS Inc. Chicago IL.

Uluocak, N. 1990. Relationships among certain quality traits of white eggs. $J$. Agric. Cukurova Univ. 5:87-96.

USDA. 2000. Egg Grading Manual. USDA. AA Grade. US Department of Agriculture, Washington DC.

Yakubu, A. Ogah, D. M. and Barde, R. E. 2008. Productivity and Egg Quality characteristics of Free Range Naked Neck and Normal Feathered Nigerian Indigenous Chickens. International Journal of Poultry science. 7(6) 579585.

Zhang, L-C., Ning, Z.-H., Xu, G-Y., Hou, Z.-C. and Yangi N. 2005. Heritabilities and Genetic and Phenotypic Correlation of Egg Quality Traits in Brown-Egg Dwarf Layers. Poultry Science Association Inc. 12091213. 